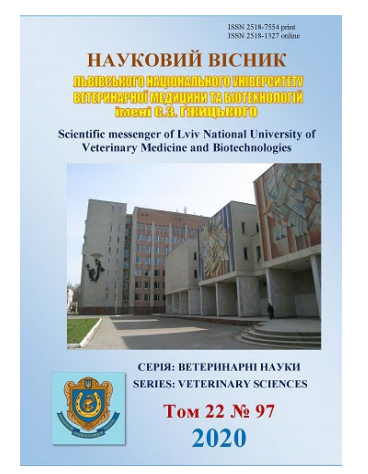

Науковий вісник Дьвівського національного університету ветеринарної медицини та біотехнологій імені С.3. Гжицького. Серія: Ветеринарні науки

Scientific Messenger of Lviv National University of Veterinary Medicine and Biotechnologies. Series: Veterinary sciences doi: 10.32718/nvlvet9726 https://nvlvet.com.ua/index.php/journal

UDC 637.524.4:033.5.003:338.432.631.11

\title{
Comparative assessment of the quality of rabbit meat, which was obtained in the conditions of a slaughter enterprise and backyard
}

\author{
R. S. Shevchik, Y. V. Duda, O. G. Gavrilina, L. V. Kuneva \\ Dnipro State Agrarian and Economic University, Dnipro, Ukraine
}

Article info

Received 18.02.2020

Received in revised form 23.03.2020

Accepted 24.03.2020

Dnipro State Agrarian and Economic University Yefremov Str., 25 Dnipro, 49027, Ukraine Tel.: +38-096-767-02-39 E-mail: rimmasvytoslavna@gmail.com
Shevchik, R. S., Duda, Y. V., Gavrilina, O. G., \& Kuneva, L. V. (2020). Comparative assessment of the quality of rabbit meat, which was obtained in the conditions of a slaughter enterprise and backyard. Scientific Messenger of Lviv National University of Veterinary Medicine and Biotechnologies. Series: Veterinary sciences, 22(97), 162-168. doi: 10.32718/nvlvet9726

Recently, healthy food products, include rabbit meat, are becoming increasingly popular consumers. Given the large percentage of households producing rabbit meat, as well as the development of relevant enterprises, the issue of quality of rabbit meat obtained under various technological conditions is relevant. The research material was two groups of Californian breed rabbits: the first (I) in the amount of 32 animals from a small rabbit farm city, the second (II) in the amount of 60 animals from a rabbit breeding and processing enterprise in the Dnipro. The experience consisted of determining: technological features of the slaughter and primary processing of rabbits, meat production and quality characteristics of rabbit meat, as well as slaughter veterinary and sanitary examination and histomorphological research. The general patterns of slaughter and primary processing of rabbits of both groups were generally similar and consistent with the requirements. The differences are defined in the methods of stunning, bleeding, toilet carcasses and preparing them for storage. A quick and effective method of bleeding rabbits of group II led to blood contamination of the skins, while in group I the skins remained clean. The dressing out percentage of rabbit backyard slaughter was $6.2 \%$ higher $(P<0.001)$ than at the enterprise, and, conversely, the loss of carcass meat juice after cooling was $3.24 \%$ less $(P<0.01)$ in production than in the small farm. The decrease in meat $\mathrm{pH}$ at the extreme minimum values per day after slaughter in the 1st group was more intense than in the 2nd group: 5.72 and $5.93(P<0.001)$, respectively. The influence of the conditions for the production of rabbit meat on the moisture and protein content in meat was not revealed. The pathological changes common to both groups of rabbits were characterized by the detection of hematomas, subcutaneous abscesses in carcasses (9.4\% and $5.0 \%$ of cases), hepatic coccidiosis (12.5\% and $18.3 \%)$. A significant difference was found in pathological changes in the lungs: the incidence of hemoaspiration of the lungs of rabbit slaughter was 16.5 times higher than that of rabbits slaughtered under production conditions.

Key words: bruising of rabbits, households, enterprises for the production of rabbit meat, technological schemes of slaughter.

\section{Порівняльна оцінка якості кролятини, отриманої в умовах забійного підприємства і приватного сектору}

\author{
Р. С. Шевчик, Ю. В. Дуда, О. Г. Гавриліна, Л. В. Кунєва
}

Дніпровський державний аграрно-економічний університет, м. Дніпро, Україна

\footnotetext{
Останнім часом все більш затребуваними споживачами стають продукти здорового харчування, до яких фахівці зараховують кролятину. Враховуючи великий відсоток господарств населення з виробництва м'яса кролів, а також розвиток відповідних підприємств, актуальним є питання порівняльної характеристики якості кролятини, отриманої за різних технологічних умов. Матеріалом дослідження були дві групи кролів каліфорнійської породи: перша (I) у кількості 32 тварини із кролеферми приватного сектору міста Дніпра, друга (II) - у кількості 60 тварин із підприємства з вирощування і переробки кролів міста Дніпра. Дослід
} 
складався з визначення: технологічних особливостей забою і первинної переробки кролів, м'ясних продуктивних та якісних характеристик кролятини, а також післязабійної ветеринарно-санітарної експертизи та гістоморфологічного дослідження. Загальні схеми забою і первинної переробки кролів обох груп загалом були схожі й відповідали вимогам. Відмінності визначені у способах оглушення, знекровлення, туалету тушок та підготовки їх до зберігання. Швидкий та ефективний спосіб знекровлення кролів ІІ групи приводив до забруднення кров'ю шкурок, тимчасом як в I групі шкури залишалися чистими. Забійний вихід тушок кролів подвірного забою був вищим на 6,2 \% (P < 0,001), ніж на підприємстві $i$, навпаки, втрати м'ясного соку тушки після охолодження були меншими на 3,24\% $(P<0,01)$ на виробництві, ніж у господарстві приватного сектору. Зниження рН м'яса до крайніх мінімальних значень через добу після забою в I групі було інтенсивнішим, ніж в II групі: 5,72 i 5,93 (P < 0,001) відповідно. Не виявлено впливу умов виробництва кролятини на вміст вологи і білка в м'ясі. Спільні для обох груп кролів патологічні зміни характеризувались виявленням гематом, підшкірних абсиесів на пушках (9,4\% і 5,0 \% випадків), еймеріозом печінки (12,5 \% і 18,3 \%). Суттєва різниця виявлена в патологічних змінах легень: частота випадків гемоаспірації легень кролів подвірного забою була в 16,5 разу вищою, ніж у кролів, забитих у виробничих умовах.

Ключові слова: забій кролів, господарства населення, підприємства з виробництва кролятини, технологічні схеми забою.

\section{Вступ}

В теперішній час актуальності здорового харчування дієтичні властивості кролятини, що обумовлені низьким вмістом холестерину, сприяють збільшенню попиту на м’ясо кролів.

Насущним питанням у кролівництві й переробному виробництві залишаються ризики під час забою, включаючи передзабійні та післязабійні етапи, що можуть вплинути на добробут тварин і безпечність та якість м'яса (Cavani et al., 2009). Гуманне поводження 3 кролями, як моральна потреба сучасного суспільства і гарантія якості кролятини, забезпечується на державному рівні в багатьох країнах світу дотриманням процедур благополуччя тварин під час виробництва (Blecha, 2015; Nielsen et al., 2020). Вченими визнана пряма залежність якості м'яса від добробуту кролів в періоди вирощування та підготовки і проведення забою (Składanowska-Baryza \& Stanisz, 2019). На якісні показники кролятини впливає багато факторів, основними 3 яких $\epsilon-$ склад раціонів, умови вирощування, годівлі, забою, переробки кролів (Okab et al., 2008; Dabbou et al., 2018; Duda et al., 2019; Fathi et al., 2019; Shevchik et al., 2019; Darmohray et al., 2019; Lesyk et al., 2020).

Оцінювання певних етапів виробництва кролятини зазвичай проводиться за показниками м'ясної продуктивності кролів, якісними характеристиками м'яса. М'ясна продуктивність кролів, яка насамперед обумовлена генетичними факторами, тісно пов'язана 3 ціновою політикою і споживацькою зацікавленістю (Wang et al., 2016), але також є відображенням адекватної системи утримання і годівлі тварин (Szendrö \& Dalle Zotte, 2011; Dalle Zotte, 2014). Якщо основні складові кролятини характеризують поживну і біологічну цінність м'яса, то показники вологості та $\mathrm{pH} \epsilon$ показовими для оцінювання технологічних властивостей і ефективності дотримання положень добробуту кролів під час підготовки та проведення забою (Chulayo \& Muchenje, 2015).

Зважаючи на те, що у Дніпропетровській області 3 151,6 тисяч кролів 92,2 \% утримуються в господарствах населення, але розвивається і промислове виробництво кролятини (Державна служба статистики України, Тваринництво України, 2019), метою роботи було порівняння якісних характеристик м’яса кролів, отриманого в умовах приватного сектору та підприємства міста Дніпра.

\section{Матеріал і методи досліджень}

Матеріалом дослідження були дві партії кролів каліфорнійської породи: перша (I) у кількості 32 тварини 3 кролеферми приватного сектору міста Дніпра, друга (II) - у кількості 60 тварин із підприємства 3 вирощування і переробки кролів міста Дніпра. Утримання кролів I і II груп було кліткове, для годівлі застосовували повнораціонні комбікорми за призначенням. Лабораторні дослідження проводили в умовах Науково-дослідного центру біобезпеки та екологічного контролю ресурсів АПК ДДАЕУ.

У забійному цеху підприємства забивали кролів II групи у віці 77 діб. Подвірний забій I групи кролів проводили у 120-денному віці в пристосованому приміщенні. Дослідження технологічних особливостей забою і первинної переробки кролів, а також ветеринарний огляд i післязабійну ветеринарно-санітарну експертизу проводили згідно з "Правилами передзабійного ветеринарного огляду i ветеринарносанітарної експертизи м'яса і м'ясопродуктів” (2002). Після зважування, визначення $\mathrm{pH}$ м'яса, продукти забою охолоджували при температурі $+4{ }^{\circ} \mathrm{C}$ упродовж 24 годин, потім визначали масу охолоджених тушок. М'ясні продуктивні характеристики тушок вимірювали або розраховували відповідності до Blasco \& Ouhayoun (1996): жива маса, маса теплої тушки, маса охолодженої тушки, забійний вихід тушки, відсоток втраченого м'ясного соку в результаті охолодження тушки, відсоток до маси тушки: печінки, нирок, серця, легень.

Якісні показники м'яса визначали в м'язах Longissimus dorsi. Для вимірювання $\mathrm{pH}$ теплих тушок (через 15 хвилин після забою $-\mathrm{pH}_{0}$ ) та охолоджених (через 24 години - $\mathrm{pH}_{24}$ ) використовували портативний $\mathrm{pH}$-метр для м'яса 3 металевим штирем (Gondo PS-45, Китай), який вводили в м'язи Longissimus dorsi на рівні 5-го поперекового, 5 і 8-го грудного хребців. Вологість м'яса визначали відповідно до ДСТУ ISO 1442:2005 (2005) “М'ясо та м'ясні продукти. Метод визначення вмісту вологи (контрольний метод)", вміст білка - біуретовим методом 3 використанням спектрофотометра марки 721-VIS (Torten \& Whitaker, 2006). Гістоморфологічні дослідження проводили 
загальноприйнятими

методами

Goralskyj et al. (2011).

\section{Результати та їх обговорення}

В результаті аналізу технологічних схем забою і первинної переробки кролів в приватному секторі населення та в цеху забійного підприємства були визначені відмінності як у способах, так і в умовах проведення технологічних операцій (табл. 1). В обох групах кролів перед забоєм витримували на голодній дієті: на підприємстві - 12 годин, у приватному господарстві - 10 годин відповідно до вимог "Правил передзабійного ветеринарного огляду і ветеринарносанітарної експертизи м'яса і м'ясопродуктів" (2002). У повідомленнях закордонних вчених про період голодування кролів перед забоєм є розбіжності з нашими державними вимогами. Trocino et al. (2003) вважають, що голодна дієта кролів не має перевищувати 6-9 годин, а Cavani \& Petracci (2004) зазначають, що за 12 годин голодування кролі втрачають 3-6 \% живої маси. Важливість тривалості передзабійного голодування кролів Dalle Zotte (2002) пов'язує з добробутом тварин, втратами ваги, ризиком бактеріального забруднення, якістю м'яса.

Умови проведення забою тварин суттєво відрізнялись. Подвірний забій кролів проводився в пристосованому приміщенні, тимчасом як забійний цех був облаштований згідно з ветеринарно-санітарними вимогами. Кролів першої групи оглушували механічним способом за допомогою палиці, а другої - електрошокером на контактному столі.

\section{Таблиця 1}

Порівняння технологічних схем забою і первинної обробки кролів в умовах забійного цеху переробного підприємства і приватного сектору

\begin{tabular}{|c|c|c|c|}
\hline \multirow{2}{*}{$\begin{array}{l}\text { № } \\
\text { 3/ח }\end{array}$} & \multirow{2}{*}{ Технологічні операції } & \multicolumn{2}{|c|}{ Групи кролів } \\
\hline & & $\mathrm{I}$ & II \\
\hline & І. Підготовча стадія & голодна дієта 10 год & голодна дієта 12 год \\
\hline & II. Основна стадія & & \\
\hline 1 & Оглушення тварин & Механічний спосіб & Електрооглушення \\
\hline 2 & Підвішування кроля за задні кінцівки & + & + \\
\hline 3 & Знекровлення & Перерізання судин шиї & Відрізання голови \\
\hline \multirow[t]{3}{*}{4} & Зняття шкури: & Вручну, “панчохою” & Вручну, “панчохою" \\
\hline & відрізання голови & + & - \\
\hline & відрізання кінцівок & передніх & передніх \\
\hline 5 & Нутрування (час після забою, хвилин) & 7,3 & 4,2 \\
\hline 6 & Туалет тушки & Сухий & Сухий і вологий \\
\hline 7 & Відділення задніх кінцівок & + & + \\
\hline \multirow[t]{2}{*}{8} & Формування тушки & - & + \\
\hline & III. Завершальна стадія & & \\
\hline 9 & Охолодження, зважування & + & + \\
\hline 10 & Пакування & Довільне & Стандартне \\
\hline 12 & Зберігання & $0 \ldots+2{ }^{\circ} \mathrm{C}$ & $0 \ldots+2{ }^{\circ} \mathrm{C}$ \\
\hline
\end{tabular}

Особливості кожного методу оглушення визначені вченими: якщо ефективність механічного оглушення кролів залежить від навичок оператора (SkładanowskaBaryzajoanna \& Stanisz, 2019), то технологічний режим електрооглушення впливає на ніжність і соковитість м'яса (Lafuente \& Lopez, 2014).

Знекровлювали кролів: I групи перерізанням судин шиї, а тварин II групи - відрізанням голови (рис. 1, 2).

Швидкий та ефективний спосіб знекровлення кролів II групи приводив до забруднення кров'ю шкурок, тимчасом як в I групі шкури залишались чистими.

Шкури з тушок знімали в обох групах за подібною технологією: операції проводились вручну, шляхом забілування, відрізанням нижніх частин передніх кінцівок, голови (для I групи) і стягуванням шкури 3 тушки у вигляді “панчохи” (рис. 3,4 ).

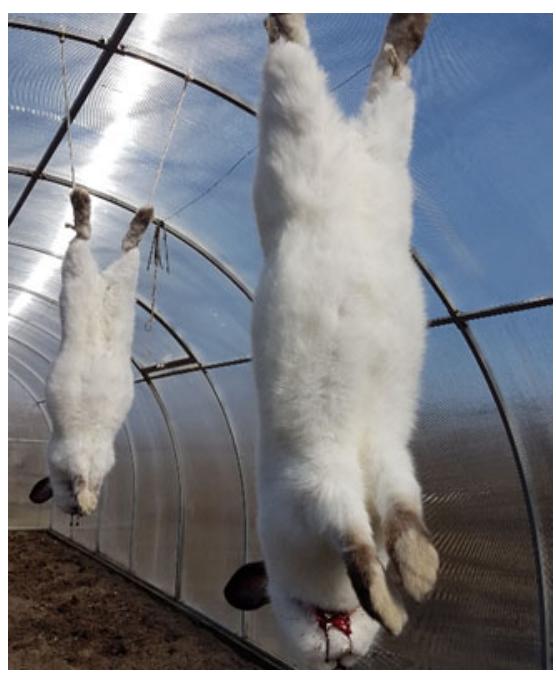

Рис. 1. Знекровлення кролів I групи 


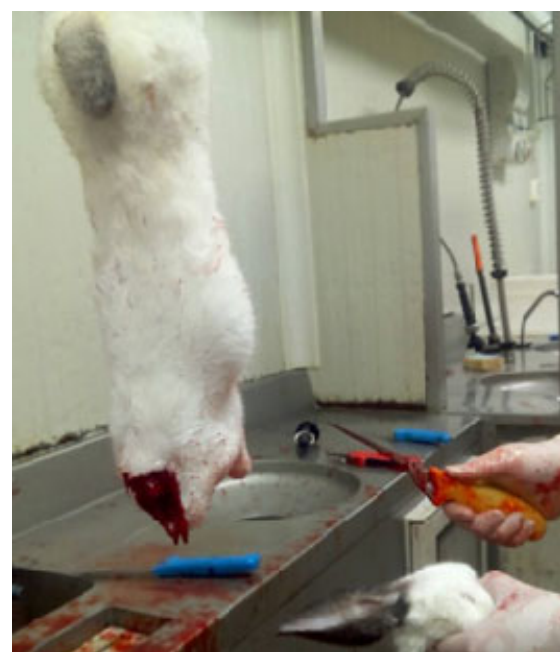

Рис. 2. Знекровлення кролів II групи

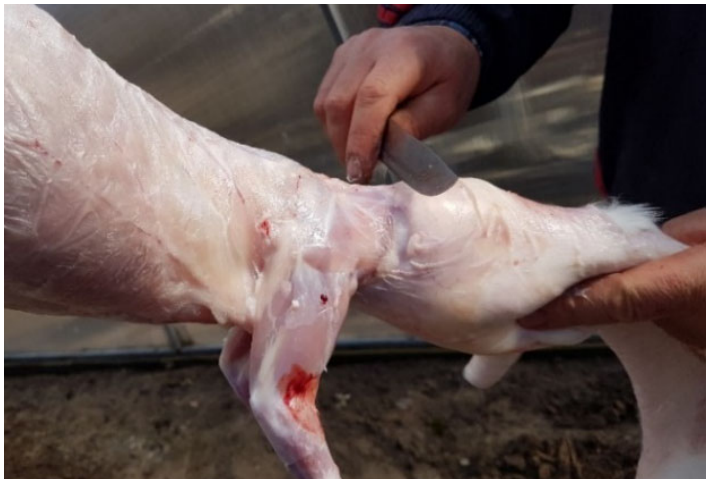

Рис. 3. Зняття шкури і відрізання голови (І група)

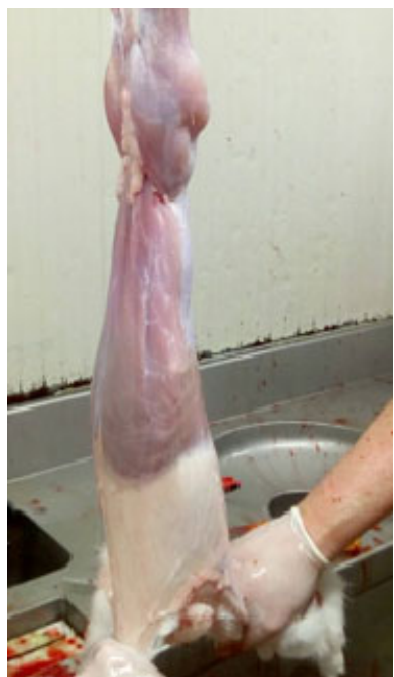

Рис. 4. Зняття шкури (II група)

Часове обмеження періоду 3 моменту знекровлення до видалення внутрішніх органів було витримано в обох групах, але у виробничих умовах цей період був коротшій майже в 2 рази, що, можливо, пояснюється навичками працівників та їх кількістю. Після нутрування тушки II групи піддавали сухому і вологому туалету, який полягав у видаленні залишків крові, механічних забруднень, волосся, у зачистці шийного зарізу і митті проточною водою за допомогою душового пристрою (рис. 5).

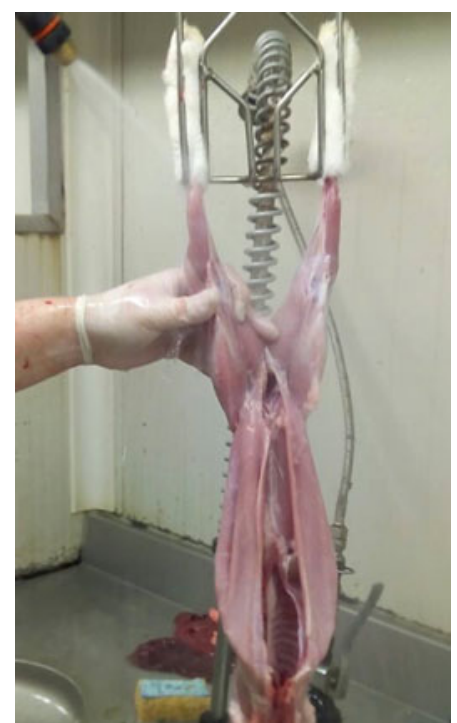

Рис. 5. Вологий туалет тушки

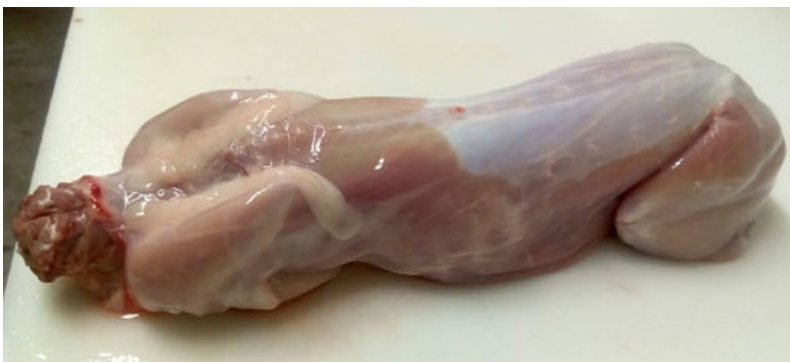

Рис. 6. Сформована тушка

Обробку тушок кролів I групи завершували сухим туалетом без промивання водою. Тушки II групи після відділення дистальних частин задніх кінцівок підлягали формуванню (рис. 6). Завершальна стадія переробки кролів загалом була схожа між групами, за винятком операції пакування.

Забійні показники кролів обох груп наведені в таблиці 2. Відповідно до національного стандарту ДСТУ 4293: 2004 "Кролі для забою” кролі I групи за живою масою $(3458,3 \pm 126,12$ г), вгодованістю, технологією вирощування і типом годівлі належали до вищої категорії, тимчасом як кролі II групи відповідали всім вимогам стандарту для вищої категорії, крім віку. Різниця у забійному віці між першою і другою групами кролів складала 43 доби, що відібражалось на живій масі та забійному виході, які були значно вищими у кролів подвірного забою: 3458,3 г проти 2612,5 та 60,6 \% проти 54,4 \% $(\mathrm{P}<0,001)$ відповідно. За повідомленням Nielsen et al. (2020), бажаний забійний вік кролів в деяких западних країнах $Є С$ становить 63-77 діб, тимчасом як в центральній Європі, особливо у дворових господарствах, перевищує 85 діб, що збігається 3 нашими дослідженнями: виробництво використовує західноєвропейську технологію забою кролів у раньому віці (77 діб), а у дворовому господарстві кролів забивають у 120 -добовому віці.

В результаті охолодження парних тушок в умовах забійного цеху виявлено менше втрат м'ясного соку на $3,24 \%(\mathrm{P}<0,01)$, ніж у дворовому господарстві, 
що пов'язано з технічними можливостями виконання операції охолодження, спрямованої на мінімізацію “холодильникових" втрат. Відсотки до маси тушки серця, печінки, легень, нирок не мали суттєвих відмінностей між групами.

\section{Таблиця 2}

М'ясні характеристики кролів, перероблених в умовах приватного сектору і забійного цеху підприємства

\begin{tabular}{|c|c|c|}
\hline \multirow{2}{*}{ Показники } & \multicolumn{2}{|c|}{ Групи } \\
\hline & $\mathrm{I}(\mathrm{n}=32)$ & II $(n=60)$ \\
\hline Жива маса, ${ }^{1}$ г & $3458,3 \pm 126,12$ & $2612,5 \pm 98,76$ \\
\hline Маса теплої тушки, г & $2096,1 \pm 35,46$ & $1421,3 \pm 80,11$ \\
\hline $\begin{array}{l}\text { Маса охолодженої } \\
\text { тушки, г }\end{array}$ & $1984,2 \pm 41,17$ & $1391,4 \pm 46,42$ \\
\hline Забійний вихід, \% & $60,6 \pm 0,73$ & $\begin{array}{l}54,4 \pm 0,53 \\
* * *\end{array}$ \\
\hline $\begin{array}{l}\text { Втрати при охолоджені } \\
\text { парної тушки, \% }\end{array}$ & $5,34 \pm 0,46$ & $\begin{array}{l}2,10 \pm 0,67 \\
* *\end{array}$ \\
\hline Серце, \% & $0,47 \pm 0,07$ & $0,42 \pm 0,15$ \\
\hline Печінка, \% & $4,8 \pm 0,93$ & $4,21 \pm 0,28$ \\
\hline Легені, \% & $0,88 \pm 0,15$ & $0,65 \pm 0,11$ \\
\hline Нирки, \% & $0,87 \pm 0,12$ & $0,99 \pm 0,34$ \\
\hline
\end{tabular}

За результатами післязабійної ветеринарносанітарної експертизи продуктів забою кролів I та II груп (табл. 3) у 9,4 та 5,0 \% випадків відповідно були виявлені травматичні пошкодження у вигляді невеликих гематом, прокусів, підшкірних абсцесів на тушках обох груп. В одиничному випадку виявлений нефрит у II групі кролів, в серці змін не встановлено взагалі.

\section{Таблиця 3}

Результати посмертного дослідження забійних кролів, перероблених в умовах подвір'я і підприємства

\begin{tabular}{lcc}
\hline \multirow{2}{*}{ Патологічні зміни, \% } & \multicolumn{2}{c}{ Групи } \\
\cline { 2 - 3 } & $\mathrm{I}(\mathrm{n}=32)$ & $\mathrm{II}(\mathrm{n}=60)$ \\
\hline Тушки & 9,4 & 5,0 \\
Легень & 28,1 & 1,7 \\
Серця & 0 & 0 \\
Печінки & 12,5 & 18,3 \\
Нирок & 0 & 1,7 \\
\hline
\end{tabular}

Суттєва різниця між групами встановлена за результатами огляду ліверу: в групі кролів подвірного забою 28,1 \% легень були з гемоаспірацією, тимчасом як в умовах підприємства зміни в легенях встановили в одному випадку $(1,7$ \%). Потрапляння крові в легені було спричинено порушенням техніки проведення операцій забою.

Понад 10 \% випадків в обох групах складала печінкова форма еймеріозу, яка характеризувалась білково-жировою дистрофією, наявністю паразитарних гранульом, розширеними жовчними ходами 3 потовщенням їніх стінок. На мікрорівні встановили, що часточкова будова паренхіми збережена, локально реєструється дискомплексація гепатоцитів. Деякі ядра клітин мають ознаки каріопікнозу або каріорексису. У цитоплазмі гепатоцитів містяться дрібні жирові краплини, що свідчить про порушення ліпідного обміну та розвиток жирової дистрофії за типом декомпозиції. Незначна кількість клітин набубнявілі, мають нерівномірно забарвлену цитоплазму, зернисті гранули ознаки білкової дистрофії органа.

В паренхімі печінки виявили інфільтрацію лімфоїдними, еозинофільними і гістіоцитарними клітинами, розростання фібробластичних елементів, які формують основу продуктивного запалення і утворюють паразитарну гранульому.

Встановили локальне порушення гемодинаміки, що проявлялося розширенням та переповненням кров'ю центральних вен печінки. Виявили розширення жовчних ходів, їх епітелій набубнявілий, цитоплазма просвітлена.

Результати наших досліджень частково збігаються 3 повідомленням Rampin et al. (2008), які дослідили 59440 тушок забитих кролів та встановили, що найчастішими ураженнями були: підшкірний абсцес та патології травної (в тому числі печінковий еймеріоз) i сечової систем.

Якісні характеристики м'яса кролів обох груп показані в таблиці 4.

\section{Таблиця 4}

Якісні показники кролятини, отриманої в умовах приватного сектору і забійного цеху підприємства

\begin{tabular}{lrc}
\hline \multirow{2}{*}{ Показники } & \multicolumn{2}{c}{ Групи } \\
\cline { 2 - 3 } & \multicolumn{1}{c}{$\mathrm{I}(\mathrm{n}=32)$} & $\mathrm{II}(\mathrm{n}=60)$ \\
\hline $\mathrm{pH}_{0}$ & $7,14 \pm 0,03$ & $7,12 \pm 0,02$ \\
$\mathrm{pH}_{24}$ & $5,72 \pm 0,02$ & $5,93 \pm 0,01 * * *$ \\
Волога, \% & $72,67 \pm 1,44$ & $71,95 \pm 1,98$ \\
Білок, \% & $21,02 \pm 1,09$ & $20,36 \pm 1,23$ \\
*** - різниця між I і II групами достовірна при $\mathrm{P}<0,001$
\end{tabular}

Визначений вміст вологи в м'ясі кролів першої і другої груп $(72,67 \pm 1,44$ і 71,95 $\pm 1,98$ \% відповідно) був трохи нижчим за середні значення вологи кролятини (73,8 \%), представлених Dalle Zotte (2014), а вміст білка в м'ясі у кролів подвірного забою майже відповідав значенням, встановленим Tavdidishvili et al. (2018) у кролів каліфорнійської породи $-21,1 \%$. При цьому нами не виявлено впливу умов виробництва кролятини на вміст вологи і білка в м'ясі. Проте зниження $\mathrm{pH}$ м'яса до крайніх мінімальних значень через добу після забою в I групі було інтенсивнішим, ніж в II групі: 5,72 і 5,93 (P < 0,001) відповідно. Можливо, це пов'язано 3 різними методами оглушення тварин, про що повідомляється в дослідженнях Lafuente \& Lopez (2014), які встановили, що при оглушенні кролів електричним струмом значення $\mathrm{pH}$ м'яса через 24 години було вище, ніж в м'ясі кролів, оглушених механічним способом. Автори пояснюють це тим, що прискорення раннього підкислення м'язів електричним струмом порушувало природній процес дозрівання м'яса. Враховуючи, що для високої якості м'яса кролів важливо, щоб показник $\mathrm{pH}$ через 24 години після забою був істотно нижчим за 6,0 (Wang et al., 2016), можна припустити, що якість кролятини, 
отриманої в умовах приватного сектору за цим показником, як і придатність до зберігання, вищі, ніж у кролів, забитих на підприємстві.

\section{Висновки}

В умовах підприємства використовується технологія раннього забійного віку кролів (77 діб), а у дворовому господарстві пізнього - 120 діб. Загальні схеми забою і первинної переробки кролів обох груп були схожі і відповідали вимогам. Відмінності виявили у способах оглушення, знекровлення, туалету тушок та підготовки їх до зберігання. Для обох груп кролів встановлена загальна тенденція з виявлення патологічних змін: гематоми, підшкірні абсцеси на тушках у 9,4 \% і 5,0 \% випадків та печінкова форма еймеріозу (12,5 \% i 18,3 \% випадків), яка характеризувалась білково-жировою дистрофією, наявністю паразитарних гранульом, розширеними жовчними ходами та порушенням гемодинаміки. Частота випадків гемоаспірації легень кролів подвірного забою була в 16,5 разу вищою, ніж у кролів, забитих у виробничих умовах. Забійний вихід тушок кролів подвірного забою був вищим на 6,2% (P < 0,001), ніж на підприємстві i, навпаки, втрати м'ясного соку тушки після охолодження були меншими на $3,24 \%(\mathrm{P}<0,01)$ на виробництві, ніж у господарстві приватного сектору. Значення $\mathrm{pH}$ м'яса через 24 години після забою були значно нижчими у кролів подвірного забою, ніж виробничого - 5,72 проти 5,93 (P <0,001).

Перспективи подальших досліджень. Зважаючи на розбіжності ветеринарно-санітарних умов забою кролів у дворових господарствах та на відповідних потужностях, у перспективі потрібні системні дослідження санітарного стану виробництва кролятини.

\section{References}

Bello, O. O., Bello, T. K., \& Adekoya, R. A. (2018). Preliminary Bacteriological Evaluation of Smoked Rabbit Meat Sold on Lagos-Benin Expressway, Nigeria. J. Food Tech. Food Chem, 1(1), 104. http://article.scholarena.co/Preliminary-

Bacteriological-Evaluation-of-Smoked-Rabbit-MeatSold-on-Lagos-Benin-Expressway-Nigeria.pdf.

Blasco, A., \& Ouhayoun, J. (1996). Harmonization of criteria and terminology in rabbit meat research. Revised proposal. World Rabbit Sci., 4(2), 93-99. doi: 10.4995/wrs.1996.278.

Blecha, J. (2015). Regulating backyard slaughter: Strategies and gaps in municipal livestock ordinances. Journal of Agriculture, Food Systems, and Community Development, 6(1), 33-48. doi: 10.5304/jafscd.2015.061.011.

Cardinali, R., Cullere, M., Dal Bosco, A., Mugnai, C., Ruggeri, S., Mattioli, S., Castellini, C., Trabalza Marinucci, M. \& Dalle Zotte, A. (2015). Oregano, rosemary and vitamin $\mathrm{E}$ dietary supplementation in growing rabbits: Effect on growth performance, carcass traits, bone development and meat chemical composition. Livestock Science, 175, 83-89. doi: 10.1016/j.livsci.2015.02.010.

Chulayo, A. Y., \& Muchenje, V. (2015). A balanced perspective on animal welfare for improved meat and meat products. South African Journal of Animal Science, 45(5), 452-469. doi: 10.4314/sajas.v45i5.2.

Cavani, C., \& Petracci, M. (2004). Rabbit meat processing and traceability. Proceedings of the 8th World Rabbit Congress, 1318-1336.

Cavani, C., Petracci, M., Trocino, A. \& Xiccato, G. (2009). Advances in research on poultry and rabbit meat quality, Italian Journal of Animal Science, 8(2), 741-750. doi: 10.4081/ijas.2009.s2.741.

Dabbou, S., Gasco, L., Rotolo, L., Pozzo, L., Tong, J. M., Dong, X. F., Rubiolo, P., Schiavone, A., \& Gai, F. (2018). Effects of dietary alfalfa flavonoids on the performance, meat quality and lipid oxidation of growing rabbits. Asian-Australasian journal of animal sciences, 31(2), 270-277. doi: 10.5713/ajas.17.0284.

Dalle Zotte, A. (2002). Perception of rabbit meat quality and major factors influencing the rabbit carcass and meat quality. Livestock Production Science, 75(1), 11-32. doi: 10.1016/S0301-6226(01)00308-6.

Dalle Zotte, A. (2014).Rabbit farming for meat purposes, Animal Frontiers, 4 (4), 62-67. doi: 10.2527/af.20140035.

Darmohray, L. M., Luchyn, I. S., Gutyj, B. V., Golovach, P. I., Zhelavskyi, M. M., Paskevych, G. A., Vishchur, V. Y. (2019). Trace elements transformation in young rabbit muscles. Ukrainian Journal of Ecology, 9(4), 616-621. https://www.ujecology.com/articles/traceelements-transformation-in-young-rabbit-muscles.pdf.

Duda, Y. V., Shevchik, R. S., \& Kuneva, L. V. (2019). The effect of Passalurus ambiguus and Cysticercus pisiformis on the yield of rabbit slaughter products. Agrarian Bulletin of the Black Sea Region, Veterinary sciences, Odessa, 93, 234-239.

Goralskyj, L. P., Khomich, V. T. \& Kononskyi, O. I. (2011). The technology of manufacturing histological preparations. In: Fundamentals of histology technique and morphofunctional research methods under norm and pathology 3rd ed, Polissia, Zhytomyr.

Fathi, M., Abdelsalam, M., Al-Homidan, I., Ebeid, T., Shehab-El-Deen, M., Abd El-Razik, M., Abou-Emera, O. \& Mostafa, M. (2019). Supplemental effects of eucalyptus (Eucalyptus camaldulensis) leaves on growth performance, carcass characteristics, blood biochemistry and immune response of growing rabbits. Annals of Animal Science, 19(3), 779-791. doi: 10.2478/aoas-2019-0023.

Lafuente, R., \& Lopez, M. (2014). Effect of electrical and mechanical stunning on bleeding, instrumental properties and sensory meat quality in rabbits. Meat Sci., 98(2), 247-254. doi: 10.1016/j.meatsci.2014.05.031.

Lesyk, Y., Ivanytska, A., Kovalchuk, I., Monastyrska, S., Hoivanovych, N., Gutyj, B., Zhelavskyi, M., Hulai, O., Midyk, S., Yakubchak, O., \& Poltavchenko,T. (2020). Hematological parameters and content of lipids in tissues of the organism of rabbits according 
to the silicon connection. Ukrainian Journal of Ecology, 10(1), 30-36. doi: 10.15421/2020 5.

Nielsen, S. S., Alvarez, J., Bicout, D.J., Calistri, P., Depner, K., Drewe, J.A., Garin-Bastuji, B., Gonzales Rojas, J. L., Gortázar Schmidt, C., Michel, V., Miranda Chueca, M. Á., Roberts, H. C., Sihvonen, L.H., Spoolder, H., Stahl, K., Velarde Calvo, A., Viltrop, A., Buijs, S., Edwards, S., Candiani, D., Mosbach-Schulz, O., Van der Stede, Y. \& Winckler, C. (2020). EFSA AHAW Panel (EFSA Panel on Animal Health and Welfare)Scientific Opinion on the health and welfare of rabbits farmed in different production systems. EFSA Journal, 18(1), 5944-5996. doi: 10.2903/j.efsa.2020.5944.

Okab, A. B., El-Banna, S. G., \& Koriem, A. A. (2008). Influence of environmental temperatures on some physiological and biochemical parameters of NewZealand rabbit males. Slovak Journal of Animal Science, 41(1), 12-19. http://www.cvzv.sk/slju/08_1/ Okab.pdf.

Rampin, F., Piccirillo, A., Schiavon, E., Poppi, L., \& Grilli, G. (2008). Detection of pathological lesions in slaughtered rabbits. Ital. J. Anim. Sci., 7, 105-111. doi: 10.4081/ijas.2008.105.

Shevchik, R. S., Duda, Y. V., Kuneva, L. V. (2019). The influence of veterinary-sanitary and technological conditions of slaughter on the microbiological parameters of rabbit meat. XVIII All-Ukrainian scientific-practical conference of young scientists "Young scientists in solving urgent problems of biology, animal husbandry and veterinary medicine", Lviv, December 5-6, 21(3), 168 (in Ukrainian).

Składanowska-Baryza, J., \& Stanisz, M. (2019). PreSlaughter Handling Implications on Rabbit Carcass and Meat Quality - A Review, Annals of Animal Science, 19(4), 875-885. doi: 10.2478/aoas-20190041.

Szendrő, Zs., \& Dalle Zotte, A. (2011). Effect of housing conditions on production and behaviour of growing meat rabbits: A review, Livestock Science, 137(1-3), 296-303. doi: 10.1016/j.livsci.2010.11.012.

Tavdidishvili, D., Khutsidze, T., \& Tsagareishvili, D. (2018). A study of the quality and biological value of meat of different breeds of rabbit bred in Georgia. Potravinarstvo Slovak Journal of Food Sciences, 12(1), 553-559. doi: 10.5219/934.

Torten, J., \& Whitaker, J. (2006). Evaluation of the Biuret and Dye-Binding Methods for Protein Determination in Meats. Journal of Food Science, 29(2), 168-174. doi: 10.1111/j.1365-2621.1964.tb01713.x.

Trocino, A., Xiccato, G., Queaque, P.б \& Sartori, A. (2003). Effect of transport duration and gender on rabbit carcass and meat quality. World Rabbit Sci., 11(1), 23-32. doi: 10.4995/wrs.2003.494.

Wang, J., Su, Y., Elzo, M. A., Jia, X., Chen, S., \& Lai, S. (2016). Comparison of Carcass and Meat Quality Traits among Three Rabbit Breeds. Korean journal for food science of animal resources, 36(1), 84-89. doi: 10.5851/kosfa.2016.36.1.84. 